\title{
SEASONAL DYNAMICS OF EPILITHIC DIATOM COMMUNITY FROM THE VRLA RIVER (SOUTHEASTERN SERBIA)
}

\author{
Olga S. Jakovljevićc1*, Slađana S. Popović ${ }^{2}$ Ivana M. Živić3 \\ Katarina Z. Stojanović3 ${ }^{3}$ Jelena Ž. Krizmanić ${ }^{1}$ \\ ${ }^{1}$ University of Belgrade, Faculty of Biology, Institute of Botany and Botanical Garden \\ „Jevremovac”, Takovska 43, 11000 Belgrade, Serbia \\ ${ }^{2}$ University of Belgrade, Instutute of Chemistry, Technology and Metallurgy, \\ Department of Ecology and Techoeconomics, Karnegijeva 4, 11000 Belgrade, Serbia \\ ${ }^{3}$ University of Belgrade, Faculty of Biology, Institute of Zoology, \\ Student Square 16, 11000 Belgrade, Serbia \\ *Corresponding author; E-mail: olga.jakovljevic@bio.bg.ac.rs
}

(Received June 29, 2020; Accepted December 12, 2020)

\begin{abstract}
Seasonal analysis of epilithic diatom community from the Vrla River was performed in four seasons a year (six times) at six sampling sites. Between the second (VR2) and the third sampling site (VR3) was located a trout fish farm. The highest number of diatom taxa was recorded in spring (149) and the lowest in autumn (93). The number of taxa that were found to be dominant during all four seasons was twenty-four. The relationship between 45 the best fitted diatom taxa, which showed conspicuous seasonal dynamics, and seasons in which these taxa were recorded was illustrated using canonical correspondence analysis (CCA). The large number of taxa was identified in all four seasons or in winter period only. Few taxa were present only in spring and summer.
\end{abstract}

Keywords: seasonal dynamics, epilithic diatom community, Vrla River.

\section{INTRODUCTION}

Diatoms play a key role in aquatic ecosystems for millions of years, as one of the most important primary producers on Earth. This group of algae is a valuable resource of very important chemical compounds, therefore has found application in the food, chemical and pharmaceutical industry, as well as the synthesis of biofuels (BOZARTH et al., 2009). Their application in paleoecology and, in recent years, in forensics is also very important (KALE and KARTHICK, 2015; WAGNER et al., 2017). However, diatoms have been widely used in systemic monitoring of surface waters, which is necessary, according to the Water Framework Directive (WFD, 2000) (SIMIĆ et al., 2018). Also, ecological status assessment of surface waters in Serbia is performed by studying diatoms, calculating the value of two diatom indices (OfFicial GAZETTE OF THE RePubliC OF SERBIA 74/2011). Temporal and spatial dynamics research of diatom communities is obligatory to understand the structure and dynamics of aquatic ecosystems, but also a required and effective tool for ecological status assessment (HwANG et al., 2011). The study of diatoms in rivers and streams mainly referred 
to their role in monitoring, while the temporal and spatial dynamics of communities were less studied (LAVOIE et al., 2008). Also, their seasonal and annual dynamics were often studied separately (SOININEN and ELORANTA, 2004).

Numerous studies from Europe and North America on the seasonal dynamics of algae indicate regular seasonal patterns in rivers and streams in the temperate climate zone (LEIRA and SABATER, 2005; KÖSTER and PIENITZ, 2006). Diatoms are dominant during the winter and continue to be the main component of the algal flora during the spring and early summer, although the composition of the species changes. Other groups of algae become dominant during the summer. Diatoms' diversity and biomass of rivers in the temperate climate zone, are the greatest during the spring, while the second maximum usually occurs in the autumn. In these rivers, seasonal changes are primarily due to differences in light availability and nitrogen concentration (ALLAN and CASTILLO, 2007).

A large number of environmental factors and their interactions affect the diatom community structure and composition in rivers and streams (KOEDOODER et al., 2019). These are complex and dynamic aquatic ecosystems in which physical and chemical parameters vary, affecting the living world in them in different ways (LENGYEL, 2016). Physical and chemical parameters that most affect the composition of diatom communities are chemical properties of water (especially $\mathrm{pH}$, ion, and nutrient concentration), substrate composition, flow rate, light, water temperature and grazing. Most of these factors depend on climate, geology, topography, land use and other relief characteristics, which explains the similarity of the composition of diatom communities in regions with similar ecological conditions (BERE and TUNDISI, 2009).

The temporal dynamics of diatom communities also depends on the species diversity in the community (MYKRÄ et al., 2011). Thus, in communities with high diversity, abundance of some species can vary greatly, without a huge impact on the community composition and biomass. In low-diversity communities, small changes of diversity have a major impact on community composition. Productivity and ecosystem size can also affect the temporal dynamics of diatom communities (KOEDOODER et al., 2019). There is a difference in the composition of diatom communities in rivers and streams of different productivity. If the composition of diatom communities is observed at regional level, local ecological parameters directly affect the composition of diatom communities. However, many factors and processes (e.g., land use and ecosystem interactions) operate within larger geographical areas and affect conditions at the local level (LAMBERTI et al., 2010). So, if the influence of factors within different spatial units is not considered, important ecological information can be missed, thus alleviating the significance of some biotic and abiotic factors on the temporal dynamics of diatom communities.

Diatom study of the Vrla River has been referred to water quality assessment (JAKOVLJEVIĆ et al., 2015, 2016, 2016b) and diversity (JAKOVLJEVIĆ, 2015; JAKOVLJEVIĆ and KRIZMANIĆ, 2015; KRIZMANIĆ et al., 2016) without temporal and spatial analysis of community structure and composition.

Seasonal study of epilithic diatom community from the Vrla River aimed to: (1) compare diversity of diatom taxa throughout the seasons at investigated sites, (2) determine dominant diatom taxa in each season and (3) examine the seasonal persistence and stability of diatom community.

\section{MATERIALS AND METHODS}

\section{Study area and location data}

The Vrla River is located in Southeastern Serbia (Figure 1). Debelska Dolina and Viljekoštica rivers are connected between Vardenik Mountain and Vlasina Lake building the Vrla River. In the upper part of the river there are high mountains with forest vegetation, 
while downstream are meadows, pastures, orchards and vineyards. In the Vladičin Han town, the Vrla River flows into the South Morava River. The length of the Vrla River is about 28 $\mathrm{km}$ and belongs to the Black Sea Basin (ĐEKOvić et al., 2010). Four hydroelectric power stations were built in the lower part of the river, while a trout farm was built in the upper part of the river.

Our investigation of the Vrla River was performed during 2011-2012 in four seasons: spring (May 2011 and 2012), summer (July 2011 and September 2012), autumn (November 2011) and winter (March 2012) at six sampling sites (VR1 - N $42^{\circ} 37.779$, E $22^{\circ} 18.092$; VR2

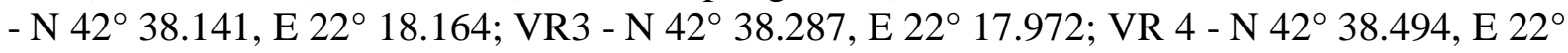
17.938; VR5 - N $42^{\circ} 39.002$, E $22^{\circ} 17.699$; VR6 - N 42 39.902 , E $\left.22^{\circ} 17.634\right)$. Sampling was carried out in a $5 \mathrm{~km}$ long section of the Vrla River, which represents upper part of the river. Between the second (VR2) and the third sampling site (VR3) a trout fish farm is located. Two sampling sites were selected before the farm and four after the farm: VR1 - 770 $\mathrm{m}$ upstream of the farm, VR2 - $50 \mathrm{~m}$ upstream of the farm, VR3 - $50 \mathrm{~m}$ downstream of the farm, VR4 - $450 \mathrm{~m}$ downstream of the farm, VR5 - $1.6 \mathrm{~km}$ downstream of the farm and VR6 $3.4 \mathrm{~km}$ downstream of the farm (Figure 1).

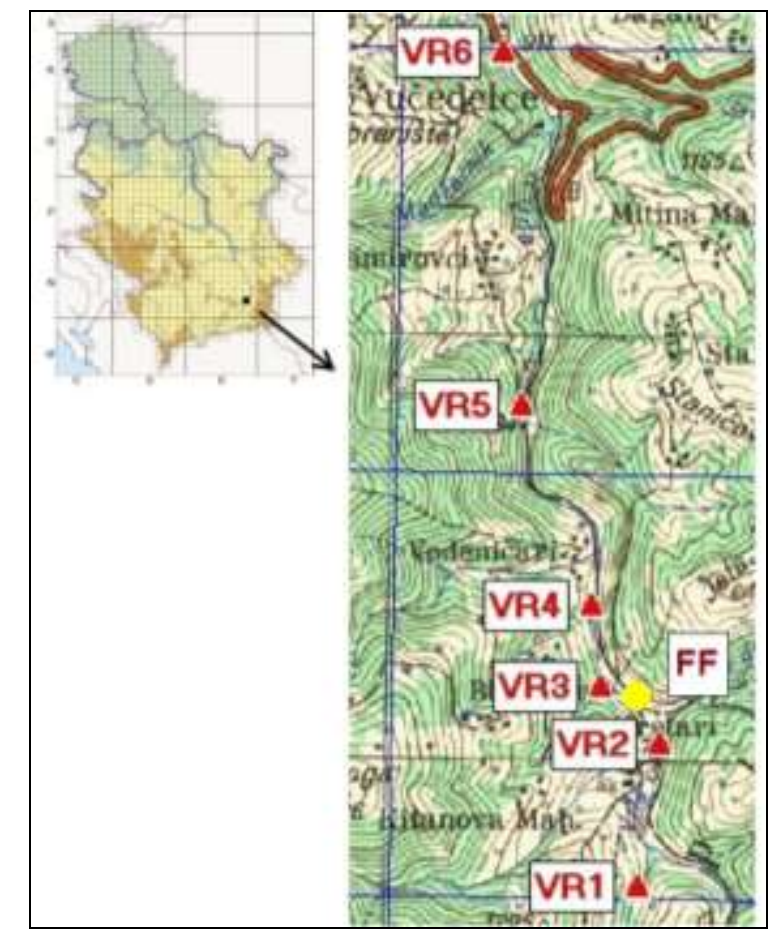

Figure 1. Position of the Vrla River in Serbia (left), sampling sites (VR1-VR6) and fish farm (FF) (right).

\section{Diatom sampling}

Epilithic diatom samples were collected by removing from stones with a toothbrush and were placed in a plastic bottles (100 ml volume) according to following standard (EN 13946, 2015). The algological materials were preserved in $4 \%$ formaldehyde. A total of 36 epilithic diatom samples were collected from May 2011 to March 2012 during four seasons (six months) at six sampling sites. 


\section{Laboratory method}

Laboratory processing of diatoms, which aims to remove organic content, was carried out applying the standard method (KRAMMER and LANGE-BERTALOT, 1986). This method involves the use of hot $\mathrm{H}_{2} \mathrm{SO}_{4}$ and $\mathrm{KMnPO}_{4}$ to obtain cleaned diatom frustules. In this way, during microscopy, different details of the diatoms cell wall become visible, which is necessary for their identification. Before microscopic analysis, permanent diatom slides were made. Prepared material was air-drying on cover glasses and mounted in Naphrax ${ }^{\circledR}$ synthetic medium.

\section{Microscopic, data and statistical analysis}

Microscopic analysis of permanent diatom slides was performed using a $1000 \mathrm{x}$ and 1600 x magnifications of Carl Zeiss AxioImager.M1 microscope, with AxioCam MRc5 camera and AxioVision 4.8 software.

Both qualitative and quantitative analysis of samples was done. Taxa were identified using the following literature: KRAMMER and LANGE-BERTALOT (1986, 1988, 1991, 2004), REICHARDT and LANGE-BERTALOT (1991), REICHARDT (1997, 1999), KRAMMER (1997, 1997a, 2000, 2002, 2003), LANGE-BERTALOT (2001), VAN DE VIJVER et al. (2004), LEVKOV (2009), LANGE-BERTALOT et al. (2011, 2017), HOFMANN et al. (2013), LEVKOV et al. (2013, 2016). Relative abundance of identified taxa (\%) was determined by counting about 400 valves of epilithic diatoms at each permanent slide. It was the way to present quantitative analysis.

Canonical correspondence analysis (CCA) was used to illustrate the relationship of recorded diatom taxa (presence/absence) and sampling seasons. The analysis was done using the CANOCO program for Windows, Version 5.0 (TER BRAAK and SMILAUER, 2012).

\section{RESULTS}

The number of recorded taxa throughout all seasons and at all sampling sites is shown in Figure 2. By analyzing diversity for each season, considering all sampling sites, the highest diversity of diatoms was observed in spring and the lowest in autumn. The number of taxa that were found to be dominant during all four seasons was twenty-four. Their relative abundance was greater than $5 \%$ at least at one site and one season.

A total of 149 diatom taxa were recorded in the Vrla River during the spring season (May 2011 and 2012) (Figure 2). The highest number of taxa during this season was documented at VR5 sampling site (a total of 60 taxa in May 2011, and 79 taxa in May 2012). The lowest number of taxa was observed at VR1 sampling site (a total of 57 taxa in May 2011, and 61 taxa in May 2012) (Figure 2).

The number of dominant taxa, in the Vrla River during the spring season, was 14 . Their relative abundance was greater than $5 \%$ at least at one site (Table 1). These taxa occured at all sampling sites during the spring period. Achnanthidium minutissimum (Kütz.) Czarnecki (24.5\%), Gomphonema elegantissimum Reichardt \& Lange-Bertalot (19.8\%) and Nitzschia soratensis $(20.05 \%)$ were defined as dominant taxa. A. minutissimum was dominant taxon at VR2, VR3 and VR6 sampling sites in May 2011, G. elegantissimum at the VR1 site in May 2011, and N. soratensis Morales \& Vis at VR4 and VR5 sites in May 2012 (Table 1).

Species richness during the summer (July and September 2011) included 140 diatom taxa (Figure 2). At VR4 sampling site was identified the largest number of taxa (64 taxa in July 2011 and 72 taxa in September of the same year). The lowest number of taxa was identified at VR1 sampling site (51 taxa in July 2011 and 40 taxa in September of the same year) (Figure 2). 


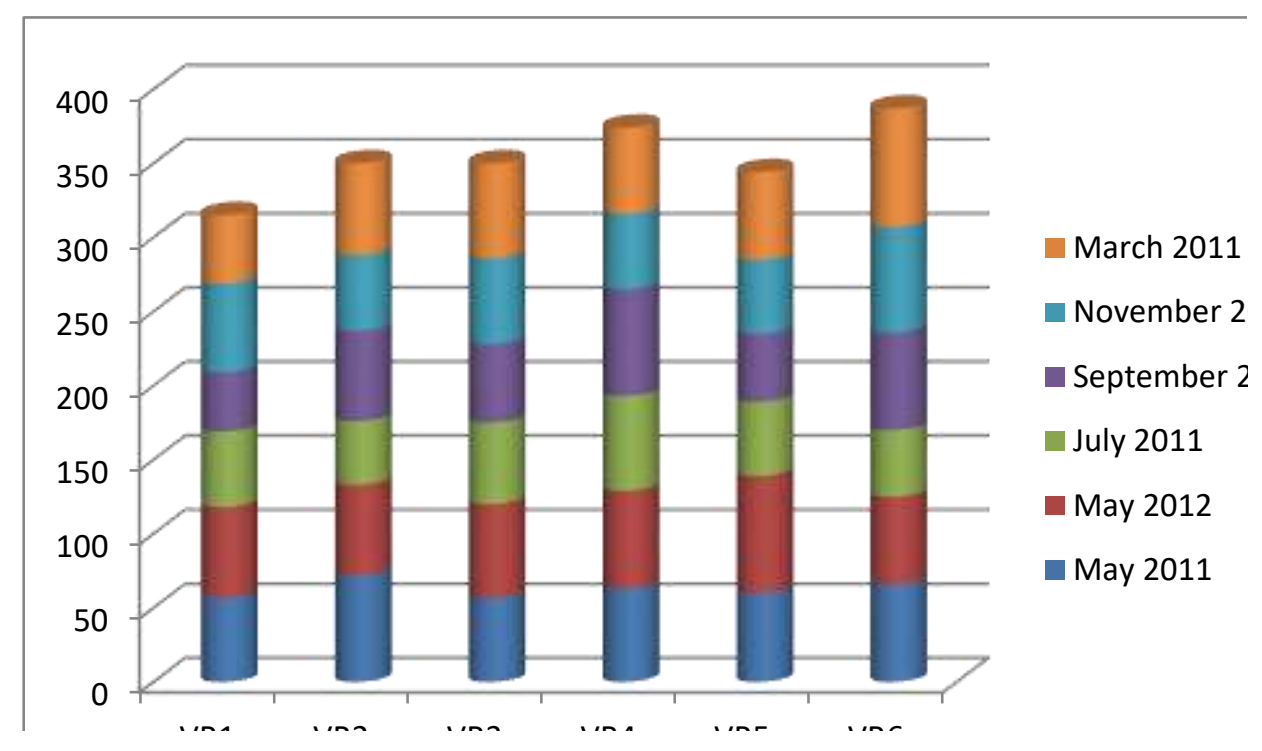

Figure 2. The number of recorded taxa in the Vrla River at six sampling sites (VR1-VR6) during four sampling seasons: spring (May 2011 and 2012), summer (July 2011 and September 2012), autumn (November 2011) and winter (March 2012).

The presence of 16 taxa with a relative abundance greater than $5 \%$ at least at one site was determined in summer (Table 2). Of these, 12 taxa occurred at all sites. Achnanthidium subatomus (Hust.) Lange-Bertalot (19.41\%), Cocconeis lineata (Ehrenberg) Van Heurck (31.68\%), C. pseudolineata (Geit.) Lange-Bertalot (24.57\%) and Nitzschia soratensis (24.07\%) were determined as dominant. A. subatomus represented dominant taxon at VR2 sampling site in July 2011, C. lineata at VR5 and VR6 in September 2011, C. pseudolineata at VR1 in September 2011 and N. soratensis at VR3 and VR4 in July 2011 (Table 2).

Diversity of diatom taxa in autumn (November 2011) period was much lower than in the previous two seasons and included a total of 93 taxa (Figure 2). VR6 sampling site characterized by the highest number of taxa (71 taxa) and VR5 the lowest (50 taxa). The number of taxa with a relative abundance greater than $5 \%$ at least at one site was 14 (Table 3). Of these, 12 taxa occurred at all 6 sites. Nitzschia soratensis was the dominant taxon at 4 sites (VR3, VR4, VR5 and VR6) with a relative abundance of $11.91 \%$ to $40.2 \%$. Achnanthidium subatomus was dominant taxon at VR1 (14.64\%) and Cocconeis lineata at VR2 (14.89\%) (Table 3).

By analyzing diatom taxa richness in winter period (March 2012), the number of recorded taxa was 121 (Figure 2). VR6 sampling site stood out as the site with the largest number of taxa ( 81 taxa) and VR1 with the lowest (46 taxa). The other three sites were characterized by a similar number of taxa (VR2 - 62 taxa, VR3 - 64 taxa and VR4 - 58 taxa). A total of 16 dominant diatom taxa were identified (Table 4). Achnanthidium minutissimum represented dominant taxon at VR3 (10.92\%) and VR6 (15.38\%), Hannaea arcus (Ehr.) R.M.Patrick at VR4 (23.33\%) and VR5 (16.34\%), and Nitzschia pura Hustedt at VR1 (13. $15 \%)$ and VR2 (15.14\%) (Table 4).

Figure 3 presents the relationship between 45 the best fitted diatom taxa, which showed conspicuous seasonal dynamics, and seasons in which these taxa were recorded. In addition to the large number of taxa identified in all four seasons, i.e., more than two seasons (central part of the chart), groups of taxa recorded only in spring (i.e. Humidophila contenta (Grun.) Lowe et al.), summer (i.e., Eunotia minor (Kütz.) Grunow and Navicula oligotraphenta Lange-Bertalot \& Hofmann) and winter period were also distinguished. It can be noticed that a very large group of taxa was distinguished and connected to winter period. 
Table 1. Relative abundance of diatom taxa (\%) present in the epilithic diatom community in the Vrla River during the spring period (May 2011 and 2012).

\begin{tabular}{|c|c|c|c|c|c|c|c|c|c|c|c|c|}
\hline \multirow{5}{*}{ Taxon } & \multicolumn{12}{|c|}{ Spring } \\
\hline & \multicolumn{6}{|c|}{ May 2011} & \multicolumn{6}{|c|}{ May 2012} \\
\hline & \multicolumn{12}{|c|}{ Sampling site } \\
\hline & VR1 & VR2 & VR3 & VR4 & VR5 & VR6 & VR1 & VR2 & VR3 & VR4 & VR5 & VR6 \\
\hline & \multicolumn{12}{|c|}{ Relative abundance of taxon $(\%) *$} \\
\hline Achnanthidium minutissimum (Kütz.) Czarnecki & 16.5 & 24.5 & 18.5 & 16 & 18.6 & 22 & 16.4 & 10.4 & 15.8 & 18.3 & + & 9.8 \\
\hline Achnanthidium subatomus (Hust.) Lange-Bertalot & 10.6 & 7.6 & 5.6 & + & 6.4 & + & 6.2 & + & 5.2 & + & 6.1 & + \\
\hline Amphora pediculus (Kütz.) Grunow & 6.6 & + & + & + & + & + & + & + & 5.6 & + & + & + \\
\hline Gomphonema elegantissimum Reichardt \& Lange-Bertalot & 19.8 & 19 & 6.9 & + & + & 6.9 & + & 7.9 & 5.4 & + & + & 5.6 \\
\hline Hannaea arcus (Ehr.) R.M.Patrick & + & + & 7.1 & 18.2 & 13.9 & 8.6 & + & + & + & + & + & + \\
\hline Mayamaea permitis (Hust.) Lange-Bertalot & + & + & + & + & / & + & 5.7 & + & + & + & + & + \\
\hline Nitzschia frustulum (Kütz.) Grunow & + & + & + & 6.1 & 6.7 & + & + & / & + & + & + & / \\
\hline Nitzschia pura Hustedt & 8.9 & + & 15.3 & 18.5 & 15.6 & 7.1 & + & + & / & + & + & + \\
\hline Nitzschia soratensis Morales \& Vis & + & + & 11.3 & + & 8.9 & 19.5 & 8.4 & + & 6.1 & 19.3 & 20 & 9.1 \\
\hline Odontidium mesodon (Kütz.) Kützing & + & + & + & 6.1 & + & + & 9.2 & 7.6 & 9.9 & + & 5.9 & + \\
\hline Planothidium frequentissimum (Lang.-Bert.) Lange-Bertalot & + & 5.9 & + & + & + & + & + & 7.6 & 7.1 & 7.6 & + & + \\
\hline Planothidium lanceolatum (Bréb. ex Kütz.) Lange-Bertalot & + & 6.4 & + & + & 8.4 & 5.9 & 8.2 & 15.6 & 12.8 & 6.4 & 7.4 & 16.7 \\
\hline Reimeria sinuata (W.Greg.) Kociolek \& Stoermer & + & + & + & + & + & + & 5.4 & + & + & + & 5.4 & 6.4 \\
\hline Sellaphora nigri (De Not.) C.E.Wetzel \& L.Ector & + & + & + & + & + & + & + & 5.2 & + & + & I & + \\
\hline
\end{tabular}

$(*)$ - Taxa with a relative abundance greater than $5 \%$ at least at one site are shown in Table 1;

(+) - Relative abundance of taxon less than 5\%;

(/) - Taxon not recorded. 
Table 2. Relative abundance of diatom taxa (\%) present in the epilithic diatom community in the Vrla River during the summer period (July and September 2011).

\begin{tabular}{|c|c|c|c|c|c|c|c|c|c|c|c|c|}
\hline \multirow{5}{*}{ Taxon } & \multicolumn{12}{|c|}{ Summer } \\
\hline & \multicolumn{6}{|c|}{ July 2011} & \multicolumn{6}{|c|}{ September 2011} \\
\hline & \multicolumn{12}{|c|}{ Sampling site } \\
\hline & VR1 & VR2 & VR3 & VR4 & VR5 & VR6 & VR1 & VR2 & VR3 & VR4 & VR5 & VR6 \\
\hline & \multicolumn{12}{|c|}{ Relative abundance of taxon $(\%) *$} \\
\hline Achnanthidium minutissimum (Kütz.) Czarnecki & 17.2 & 15.9 & 14.1 & 18.8 & 15.1 & + & + & 8.6 & 16.3 & 14.6 & 8.4 & 5.4 \\
\hline Achnanthidium subatomus (Hust.) Lange-Bertalot & 5.9 & 19.4 & 6.2 & + & 14.1 & 7.6 & + & 5.6 & + & 5.1 & 8.4 & + \\
\hline Amphora pediculus (Kütz.) Grunow & 6.1 & + & + & + & + & + & 7.6 & 5.4 & + & + & + & + \\
\hline Cocconeis neodiminuta Krammer & + & + & / & l & / & + & 5.4 & + & / & + & + & + \\
\hline Cocconeis lineata (Ehrenberg) Van Heurck & + & + & + & + & + & 12.5 & 24.5 & 12.8 & 15.8 & 17.1 & 23.7 & 31.6 \\
\hline Cocconeis placentula Ehrenberg & + & + & + & / & + & + & 10.9 & + & 5.6 & + & 11.8 & 10.4 \\
\hline Cocconeis pseudolineata (Geit.) Lange-Bertalot & 5.1 & + & + & + & + & 18.7 & 24.5 & 13.6 & + & + & 6.6 & 9.6 \\
\hline Gomphonema elegantissimum E.Reichardt \& Lange-Bertalot & 15.8 & 11.3 & + & + & 14.1 & 15.5 & + & + & + & + & + & + \\
\hline Gomphonema parvulum Kützing & / & / & + & + & + & + & / & + & 9.6 & + & / & + \\
\hline Mayamaea permitis (Hust.) Lange-Bertalot & + & 8.6 & 6.9 & 11.6 & + & + & + & + & + & 6.3 & + & + \\
\hline Nitzschia archibaldii Lange-Bertalot & / & / & + & + & / & / & / & + & 10.8 & + & + & / \\
\hline Nitzschia soratensis Morales \& Vis & + & + & 24 & 23 & 23.5 & 18.7 & + & 7.4 & 6.4 & 15.1 & 17.8 & 21.2 \\
\hline Planothidium frequentissimum (Lang.-Bert.) Lange-Bertalot & 6.1 & + & + & + & + & / & + & + & + & + & + & / \\
\hline Planothidium lanceolatum (Bréb. ex Kütz.) Lange-Bertalot & 16.3 & 13 & + & 7.1 & + & + & 7.6 & 10.1 & + & + & + & + \\
\hline Reimeria sinuata (W.Greg.) Kociolek \& Stoermer & 6.4 & + & 5.4 & + & 9.6 & + & + & + & + & + & + & + \\
\hline Sellaphora nigri (De Not.) C.E.Wetzel \& L.Ector & + & 5.4 & 8.9 & + & + & / & + & 6.4 & + & + & + & + \\
\hline
\end{tabular}

(*) - Taxa with a relative abundance greater than $5 \%$ at least at one site are shown in Table 1;

(+) - Relative abundance of taxon less than 5\%;

(/) - Taxon not recorded. 
Table 3. Relative abundance of diatom taxa (\%) present in the epilithic diatom community in the Vrla River during the autumn period (November 2011).

\begin{tabular}{|c|c|c|c|c|c|c|}
\hline \multirow{4}{*}{ Taxon } & \multicolumn{6}{|c|}{ Autumn (November 2011) } \\
\hline & \multicolumn{6}{|c|}{ Sampling site } \\
\hline & VR1 & VR2 & VR3 & VR4 & VR5 & VR6 \\
\hline & \multicolumn{6}{|c|}{ Relative abundance of taxon $(\%)^{*}$} \\
\hline Achnanthidium minutissimum (Kütz.) Czarnecki & 8.9 & + & 5.2 & 13.9 & 22.3 & 6.9 \\
\hline Achnanthidium jackii Rabenhorst & + & 5.2 & + & + & I & + \\
\hline Achnanthidium subatomus (Hust.) Lange-Bertalot & 14.6 & + & + & + & 7.4 & + \\
\hline Amphora pediculus (Kütz.) Grunow & + & + & 5.2 & + & + & 7.4 \\
\hline Cocconeis neodiminuta Krammer & + & 6.9 & + & + & + & 7.6 \\
\hline Cocconeis lineata (Ehrenberg) Van Heurck & + & 14.8 & + & + & + & + \\
\hline Cocconeis placentula Ehrenberg & + & 5.7 & + & + & + & + \\
\hline Cocconeis pseudolineata (Geit.) Lange-Bertalot & + & + & + & + & + & 12.4 \\
\hline $\begin{array}{l}\text { Gomphonema elegantissimum Reichardt \& Lange- } \\
\text { Bertalot }\end{array}$ & + & 8.6 & 7.6 & + & + & + \\
\hline $\begin{array}{l}\text { Gomphonema pumilum var. rigidum Reich. \& Lange- } \\
\text { Bertalot }\end{array}$ & + & 11.1 & + & + & + & / \\
\hline Nitzschia pura Hustedt & + & + & + & 6.7 & I & + \\
\hline Nitzschia soratensis Morales \& Vis & 7.6 & + & 11.9 & 19.8 & 40.2 & 29.2 \\
\hline $\begin{array}{l}\text { Planothidium lanceolatum (Bréb. ex Kütz.) Lange- } \\
\text { Bertalot }\end{array}$ & 7.9 & 8.1 & 10.4 & 7.6 & + & + \\
\hline Reimeria sinuata (W.Greg.) Kociolek \& Stoermer & 6.2 & + & + & 7.2 & + & + \\
\hline Sellaphora nigri (De Not.) C.E.Wetzel \& L.Ector & 6.4 & + & + & 5.2 & + & + \\
\hline
\end{tabular}

(*) - Taxa with a relative abundance greater than $5 \%$ at least at one site are shown in Table 1; (+) - Relative abundance of taxon less than $5 \% ;(/)$ - Taxon not recorded.

Table 4. Relative abundance of diatom taxa (\%) present in the epilithic diatom community in the Vrla River during the winter period (1 March 2012).

\begin{tabular}{lccccccc}
\hline & \multicolumn{5}{c}{ Winter (1 March 2012) } \\
\cline { 2 - 7 } Taxon & \multicolumn{5}{c}{ Sampling site } \\
\cline { 2 - 7 } & VR1 & VR2 & VR3 & VR4 & VR5 & VR6 \\
\cline { 2 - 7 } & \multicolumn{7}{c}{ Relative abundance of taxon (\%)* } \\
\hline Achnanthidium minutissimum (Kütz.) Czarnecki & 9.1 & 7.6 & 10.9 & 14.8 & 13.3 & 15.3 \\
Achnanthidium jackii Rabenhorst & + & + & + & + & + & 8.4 \\
Achnanthidium subatomus (Hust.) Lange-Bertalot & + & 8.1 & 5.7 & + & 14.1 & + \\
Amphora pediculus (Kütz.) Grunow & 7.4 & + & 7.4 & + & + & 7.4 \\
Cocconeis neodiminuta Krammer & 5.9 & + & + & + & + & + \\
Cocconeis pseudolineata (Geit.) Lange-Bertalot & 6.2 & + & + & + & + & $/$ \\
Denticula tenuis Kützing & $/$ & $/$ & $/$ & + & $/$ & 6.2 \\
Gomphonema elegantissimum Reich. \& Lange-Bertalot & + & + & 5.4 & 5.2 & + & + \\
Hannaea arcus (Ehr.) R.M.Patrick & 9.6 & 12.4 & 7.9 & 23.3 & 16.3 & 6.7 \\
Navicula tripunctata (O.F.Müll.) Bory & + & + & + & + & + & 5.4 \\
Nitzschia fonticola (Grun.) Grunow & $/$ & + & + & + & + & 9.9 \\
Nitzschia frustulum (Kütz.) Grunow & $/$ & 6.2 & + & + & + & $/$ \\
Nitzschia pura Hustedt & 13.1 & 15.1 & 5.46 & 8.93 & 6.44 & + \\
Nitzschia soratensis Morales \& Vis & + & + & 7.9 & 9.9 & + & + \\
Odontidium mesodon (Kütz.) Kützing & + & 5.7 & + & + & 8.4 & + \\
Planothidium lanceolatum (Bréb. ex Kütz.) Lange- & + & 5.2 & + & + & + & + \\
Bertalot & & & & + & + \\
\hline
\end{tabular}

(*) - Taxa with a relative abundance greater than $5 \%$ at least at one site are shown in Table $1 ;(+)$ - Relative abundance of taxon less than $5 \%$; (/) - Taxon not recorded. 


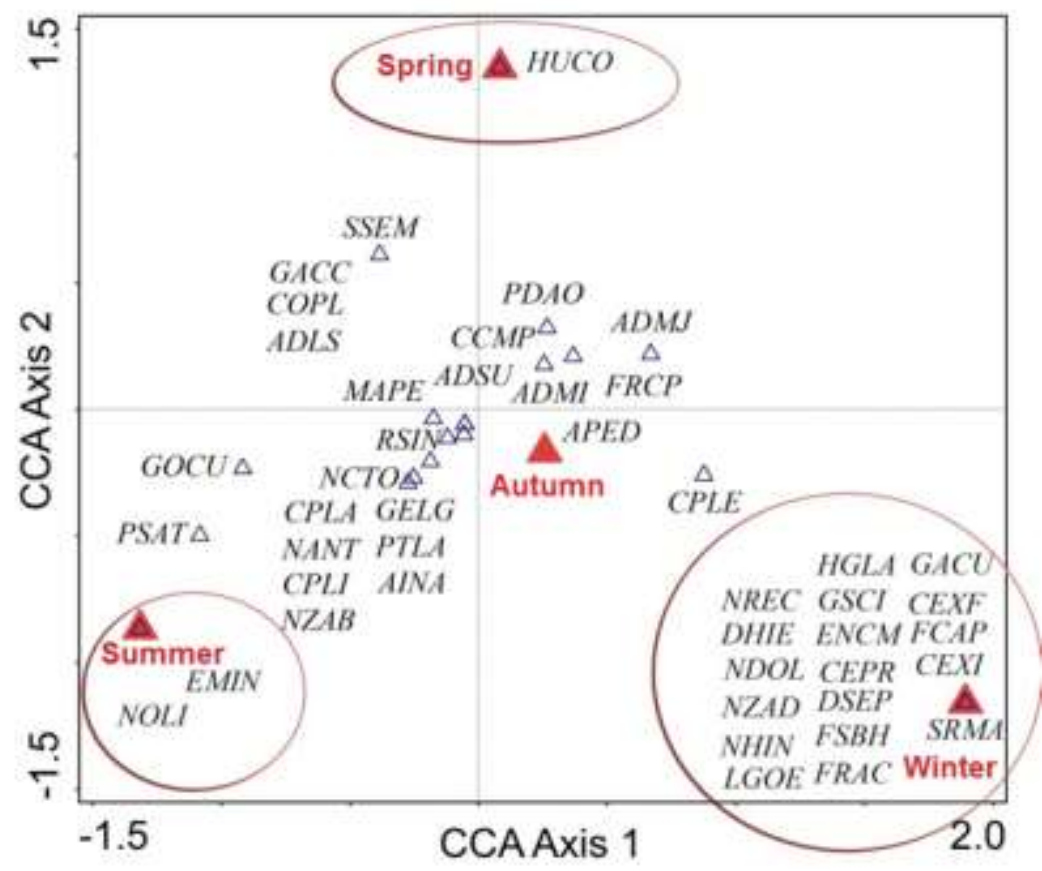

Figure 3. CCA showing the relationship between diatom taxa recorded in the Vrla River and sampling seasons. Humidophila contenta - HUCO, Sellaphora seminulum - SSEM, Geissleria acceptata -

GACC, Cocconeis pseudolineata - COPL, Adlafia suchlandtii - ADLS, Mayamaea permitis - MAPE,

Psammothidium daonense - PDAO, Cymbella compacta - CCMP, Achnanthidium subatomus - ADSU, Achnanthidium minutissimum - ADMI, Achnanthidium jackii - ADMJ, Fragilaria recapitellata -

FRCP, Reimeria sinuata - RSIN, Navicula cryptotenelloides - NCTO, Cocconeis placentula - CPLA, Gomphonema elegantissimum - GELG, Navicula antonii - NANT, Nitzschia soratensis - NZAB, Amphora pediculus - APED, Cocconeis euglypta - CPLE, Planothidium lanceolatum - PTLA, Amphora inariensis - AINA, Cocconeis lineata - CPLI, Gomphonema occultum - GOCU, Psammothidium subatomoides - PSAT, Navicula oligotraphenta - NOLI, Eunotia minor - EMIN, Nitzschia recta - NREC, Diatoma hyemalis - DHIE, Nitzschia oligotraphenta - NDOL, Nitzschia adamata - NZAD, Navicula hintzii - NHIN, Luticola goeppertiana - LGOE, Handmannia glabriuscula - HGLA, Girosygma sciotoense - GSCI, Encyonopsis microcephala - ENCM, Cymbella excisa var. procera - CEPR, Diploneis separanda - DSEP, Fallacia subhamulata - FSBH, Ulnaria acus - FRAC, Gomphonema acuminatum - GACU, Cymbella excisiformis - CEXF, Fragilaria capucina - FCAP, Cymbella exigua - CEXI, Staurosira martyi - SRMA.

\section{DISCUSSION}

The highest number of diatom taxa from the epilithic diatom community of the Vrla River (Southeastern Serbia) was recorded in spring and the lowest in autumn (Figure 1). SOININEN and ELORANTA (2004) have indicated that seasonal dynamics of diatoms depends greatly on the type of community. They pointed that epilithic diatom communities showed greater seasonal dynamics than epipelic. They recorded the highest number of diatom taxa in the epilithic communities of three boreal rivers in South Finland in September and the lowest in August. Our results are in accordance with generally accepted view that the number of diatom taxa decreases significantly in autumn and winter, while maximum diversity is reached in spring and late summer (ALLAN and CASTILLO, 2007). 
Achnanthidium minutissimum, Gomphonema elegantissimum and Nitzschia soratensis were distinguished as dominant taxa in epilithic diatom community of the Vrla River during the spring period (Table 1). A. minutissimum is a taxon of wide ecological valence, which successfully inhabits both oligotrophic and eutrophic waters (LOBO et al., 2004). Nevertheless, this taxon is usually dominant in oligotrophic waters, while its relative abundance significantly reduced in eutrophic waters (KELLY et al., 2007). The dominance of this taxon in our study is expected and confirms the good ecological status of the Vrla River (JAKOVLJEVIĆ et al., 2016). G. elegantissimum is a taxon characteristic of oligo- to weakly eutrophic running water with a carbonate base (LANGE-BERTALOT et al., 2017). Considering the composition of the substrate, as well as the ecological status of the Vrla River (JAKOVLJEVIĆ et al., 2016), dominance of this species was also expected in our study. $N$. soratensis, which occured as a dominant taxon in spring, has so far recorded only in fresh water with low temperature and $\mathrm{pH}>8$ (TROBAJO et al., 2012). However, our study showed this is not always the case, since this species was dominant at sites VR4 and VR5 in May 2012 (Table 1) where moderate temperature and $\mathrm{pH}<8$ were measured (JAKOVLJEVIĆ et al., 2016).

In addition to these three taxa, Achnanthidium subatomus, Cocconeis lineata and $C$. pseudolineata were dominant taxa in epilithic diatom community during the summer period (Table 2). According to VAN DAM et al. (1994), these two species of the genus Cocconeis are indicators of mesotrophic and eutrophic waters. Epilithic diatom communities research of streams in Sardinia testifies about the dominance of A. subatomus in winter (LAI et al., 2016). The authors pointed out there is no information on the preferences of this taxon when it comes to organic matter, still it is known to occur successfully in oligo- to mesotrophic waters. In our study, A. subatomus distinguished as the dominant taxon during three periods (summer, autumn and winter) (Tables 2, 3, 4). Nevertheless, this taxon reached the highest relative abundance during the summer (Table 2).

Taxa that were dominant during spring and summer also dominated in autumn and winter periods. Hannaea arcus and Nitzschia pura were exceptions, which dominated only in the winter (Table 4). In general, even though winter was not characterized with the highest number of taxa recorded, it was the most distinguished season according to the species composition (Figure 3). H. arcus is a taxon generally considered to be oligosaprobic and tolerates a certain level of organic pollution (LANGE-BERTALOT et al., 2017). Thus, common to all dominant taxa of the Vrla River is that they are oligosaprobes, which are widely distributed in oligo- to slightly eutrophic running waters. In general, the structure and dynamics of the epilithic diatom community from the Vrla River faithfully reflects the good ecological status of this river, which is confirmed by calculating four diatom indices (IPS, IBD, CEE and DESCY) (JAKOVLJEVIĆ et al., 2016). As mentioned before, a lot of taxa were present in all four seasons or in winter period only (Figure 3). This probably indicates that in addition to many physicochemical parameters, the seasonal dynamics of diatoms is also greatly influenced by microclimatic factors. VIRTANEN (2015) emphasized that the impacts of climate changes on the temporal dynamics of diatom communities will increase in the future, changing patterns of their composition.

\section{CONCLUSION}

Our results confirm that diatoms diversity is the highest during the spring in rivers in the temperate climate zone. As a result of seasonal sampling in the Vrla River a total of 149 diatom taxa were recorded during the spring, followed by summer (140), winter (121) and autumn (93) season. The large number of taxa (24) was identified in all four seasons. Few taxa were present only in spring and summer period (3) while a lot of taxa were present in winter period only (18). Results of our research indicate that study of the temporal dynamics 
of diatom communities in freshwaters is necessary for proper monitoring and protection of water bodies. Seasonal variation of diatom community composition was conspicuous and probably linked to seasonal variation of many physical and chemical parameters, so further, more detailed research of diatom communities should be conducted having in mind that microclimatic characteristics also play important role. It is clear that more attention should be paid in the future to the study of temporal dynamics of diatom communities in freshwaters.

\section{Acknowledgments}

Financial support was provided by the Serbian Ministry of Education, Science and Technological Development (Grant No. Grant No. 451-03-68/2020-14/ 200178 and Grant No. 451-03-9/2021-14/ 200026).

\section{References:}

[1] ANONYMOUS (2011): Pravilnik o parametrima ekološkog i hemijskog statusa površinskih voda i parametrima hemijskog i kvantitativnog statusa podzemnih voda (Sl. glasnik RS 74/2011). [in Serbian]

[2] Allan, J.D., CASTILlO, M.M. (2007): Stream ecology: structure and function of running waters. Springer Netherlands: 436 pp. doi: 10.1007/978-1-4020-5583-6

[3] BERE, T., TUNDISI, J.G. (2009): Weighted average regression and calibration of conductivity and $\mathrm{pH}$ of benthic diatom assemblages in streams influenced by urban pollutionSão Carlos/SP, Brazil. Acta Limnologica Brasiliensia 21 (3): 317-325.

[4] Bozarth, A., MAier, U.G., Zauner, S. (2009): Diatoms in biotechnology: modern tools and applications. Applied Microbiology and Biotechnology 82 (2): 195-201. doi: 10.1007/s00253-008-1804-8

[5] Đeković, V., Gajić, G., AnĐelković, A., Milošević, N., Kernalis J. (2010): The water quality in the basin of Vrla River and its impact on the environmental quality. $1^{s t}$ Serbian Forestry Congress "Future with forests", Faculty of Forestry, University of Belgrade, Belgrade: 1054-1065.

[6] EN 13946 (2015): Water quality - Guidance standard for the routine sampling and pretreatment of benthic diatoms from rivers. Institute for Standardization of Serbia.

[7] Hofmann, G., Werum, M., Lange-Bertalot, H. (2013): Diatomeen im Süßwasser Benthos von Mitteleuropa. Bestimmungs flora Kieselalgen für die ökologische Praxis. Über 700 der häufigsten Arten und ihre Ökologie. Koeltz Scientific Books, Königstein: $908 \mathrm{pp}$.

[8] Hwang, S.J., Kim, N.Y., Yoon, S.A., Kim, B.H., Park, M.H., You, K.A., LeE, H.Y., KIM, H.S., KIM, Y.J., LeE, J., LeE, O.M., Shin, J.K., LeE, E.J., JeON, S.L., JoO H.S. (2011): Distribution of benthic diatoms in Korean rivers and streams in relation to environmental variables. Annales de Limnologie - International Journal of Limnology 47: 15-33. doi: 10.1051/limn/2011017

[9] JaKOVLJEVIĆ, O. (2015): Diatom species composition of the Vrla River. International conference of young scientists "Advances in botany and ecology", Book of abstracts, Poltava (Ukraine): 39p.

[10] JAKOVLJEVIĆ, O., KRIZMANIĆ, J. (2015): Epiphytic diatoms of the genus Navicula from the Vrla River (Serbia). $18^{\text {th }}$ Symposium for Biology Students in Europe "Symbiose", Book of abstracts, Alexandroupoli (Greece): 25p. 
[11] Jakovljević, O., KRizmanić, J., Žıvić, I., BJelanović, K. (2015): Diatom indices as base of water quality assessment of the Vrla River. Water 2015: 44 ${ }^{\text {rd }}$ Annual Conference of the Serbian Water Pollution Control Society, Conference Proceedings, Kopaonik: 179-186. [in Serbian with English summary]

[12] JaKOvljević, O., Popović, S., Živić, I., Stojanović, K., KRIZMAnić, J. (2016). Benthic diatoms of the Vrla River (Serbia) and their application in the water ecological status assessment. Oceanological and Hydrobiological Studies 45 (3): 304-315. doi: 10.1515/ohs-2016-0029

[13] Jakovljević, O., Popović, S., Živić, I., Stojanović, K., Krizmanić, J. (2016b). The impact of trout fish ponds on the ecological status of the Vrla and Mlava rivers (Serbia) based on epilithic diatom communities. $V$ Congress of Ecologists of the Republic of Macedonia with International Participation, Book of abstracts, Ohrid (Macedonia): 130p.

[14] Kale, A., Karthick, B. (2015): The diatoms: Big significance of tiny glass houses. Resonance 20 (10): 919-930.

[15] Kelly, M., Juggins, S., Guthrie, R., Pritchard, S., Jamieson, J., RipPey, B., Hirst, H. YALLOP, M. (2007): Assessment of ecological status in U.K. rivers using diatoms. Freshwater Biology 53 (2): 403-422. doi: 10.1111/j.1365-2427.2007.01903.x

[16] Koedooder, C., Stock, W., Willems, A., Mangelinckx, S. (2019): Diatom-Bacteria Interactions Modulate the Composition and Productivity of Benthic Diatom Biofilms. Frontiers in Microbiology 1255 (10): 1-11. doi: 10.3389/fmicb.2019.01255

[17] KöSTER, D., PIENITZ, R. (2006): Seasonal diatom variability and paleolimnological inferences - a case study. Journal of Paleolimnology 35: 395-416. doi: 10.1007/s10933005-1334-7

[18] Krammer, K. (1997): Die cymbelloiden Diatomeen. Ein Monographie der weltweit bekannten Taxa. Teil 1. Allgemeines und Encyonema part. In: Lange-Bertalot, H., Kociolek, P. (eds.). Bibliotheca Diatomologica 36. J. Cramer, Berlin-Stuttgart: 382 pp.

[19] Krammer, K. (1997a): Die cymbelloiden Diatomeen. Teil 2. Encyonema part., Encyonopsis and Cymbellopsis. In: Lange-Bertalot, H., Kociolek, P. (eds.). Bibliotheca Diatomologica 37. J. Cramer, Berlin-Stuttgart: 469 pp.

[20] Krammer, K. (2000): The genus Pinnularia. Vol. 1. In: Lange-Bertalot, H. (ed.). Diatoms of Europe: Diatoms of European Inland Waters and comparable habitats. Gantner Verlag, Ruggell: 703 pp.

[21] Krammer, K. (2002): Cymbella. Vol. 3. In: Lange-Bertalot, H. (ed.). Diatoms of Europe: Diatoms of European Inland Waters and comparable habitats. Gantner Verlag, Ruggell: 584 pp.

[22] Krammer, K. (2003): Cymbopleura, Delicata, Navicymbula, Gomphocymbellopsis, Afrocymbella. Vol. 4. In: Lange-Bertalot, H. (ed.). Diatoms of Europe: Diatoms of European Inland Waters and comparable habitats. Gantner Verlag, Ruggell: 530 pp.

[23] Krammer, K., LANGE-Bertalot, H. (1986): Bacillariophyceae. 1. Teil: Naviculaceae. In: Ettl, H., Gerloff, J., Heynig, H., Mollenhauer, D. (eds.). Sübwasserflora von Mitteleuropa. Gustav Fischer Verlag, Jena 2/1: 876 pp.

[24] Krammer, K., LANGe-Bertalot, H. (1988): Bacillariophyceae. 2. Teil. Bacillariaceae, Epithemiaceae, Surirellaceae. In: Ettl, H., Gerloff, J., Heynig, H., Mollenhauer, D. (eds.). Sübwasserflora von Mitteleuropa. Gustav Fischer Verlag, Stuttgart and Jena 2/2: $596 \mathrm{pp}$.

[25] Krammer, K., Lange-Bertalot, H. (1991): Bacillariophyceae. 4. Teil: Achnanthaceae. Kritische Ergänzungen zu Navicula (Lineolatae) und Gomphonema. In: Ettl, H., Gartner, G., Gerloff, J., Heynig, H., Mollenhauer, D. (eds.). Sübwasserflora von Mitteleuropa. Gustav Fischer Verlag, Stuttgart and New York 2/4: 437 pp. 
[26] Krammer, K., Lange-Bertalot, H. (2004): Bacillariophyceae. 3. Teil: Centrales, Fragilariaceae, Eunotiaceae. Sußwasserflora von Mitteleuropa 2. In: Ettl, H., Gerloff, J., Heynig, H., Mollenhauer, D. (eds.). Sübwasserflora von Mitteleuropa. Gustav Fischer Verlag, Stuttgart 2/3: 598 pp.

[27] Krizmanić, J., Jakovljević, O., Vidaković, D., Jovanović, J. (2016). First record of the genus Decussata (Patrick) Lange-Bertalot (Bacillariophyta) in Serbia - distribution of the rare species D. hexagona (Torka) Lange-Bertalot. Botanica Serbica 40 (2): 161165. doi: 10.5281/zenodo.162214

[28] Lai, G.G., Padedda, B.M., Wetzel, C.E., Lugliè, A., Sechi, N., Ector, L. (2016): Epilithic diatom assemblages and environmental quality of the $\mathrm{Su}$ Gologone karst spring (central-eastern Sardinia, Italy). Acta Botanica Croatica 75 (1): 129-143. doi: 10.1515/botcro-2016-0008

[29] LAmberti, G.A., Chaloner, D.T., Hershey, A.E. (2010): Linkages among aquatic ecosystems. Journal of the North American Benthological Society 29 (1): 245-263. doi: 10.1899/08-166.1

[30] LANGe-Bertalot, H. (2001): Navicula sensu stricto, 10 genera separated from Navicula sensu lato, Frustulia. Vol. 2. In: Lange-Bertalot, H. (ed.). Diatoms of European Inland Waters and Comparable Habitats. Gantner Verlag, Ruggell: 526 pp.

[31] Lange-Bertalot, H., BaK, M., Witkowski, A., Tagliaventi, N. (2011): Eunotia and some related genera. Vol. 6. In: Lange-Bertalot, H. (ed.). Diatoms of European Inland Waters and Comparable Habitats. Gantner Verlag, Ruggell: 747 pp.

[32] Lange-Bertalot, H., Hofmann, G., Werum, M., Cantonati, M. (2017): Freshwater Benthic Diatoms of Central Europe: Over 800 Common Species Used in Ecological Assessment. Koeltz Botanical Books: 942 pp.

[33] Lavoie, I., Campeau, S., Darchambeau, F., Cabana, G., Dillon, P.J. (2008): Are diatoms good integrators of temporal variability in stream water quality? Freshwater Biology 53 (4): 827-841. doi: 10.1111/j.1365-2427.2007.01935.x

[34] LeIRA, M., SABATER, S. (2005): Diatom assemblages distribution in Catalan rivers, NE Spain, in relation to chemical and physiographical factors. Water Research 39 (1): 73 82. doi: 10.1016/j.watres.2004.08.034

[35] LENGYel, E. (2016): Stress and disturbance in benthic diatom assemblages. Examples from lakes and streams and from the field and laboratory studies. PhD Thesis, University of Pannonia, Veszprém, Hungary.

[36] Levkov, Z. (2009): Amphora sensu lato. Vol. 5. In: LAnge-Bertalot, H. (ed.). Diatoms of the European Inland Waters and Comparable Habitats. Gantner Verlag, Ruggell: $916 \mathrm{pp}$.

[37] Levkov, Z., Metzeltin, D., Pavlov, A. (2013): Luticola and Luticolopsis. Vol. 7. In: LANGe-Bertalot, H. (ed.). Diatoms of Europe Diatoms of the European Inland Waters and Comparable Habitats. Koeltz Scientific Books, Königstein: 697 pp.

[38] Levkov, Z., Mitic-Kopanja, D., ReichardT, E. (2016): The diatom genus Gomphonema from the Republic of Macedonia. Volume 8. In: LANGE-BERTAlot, H. (ed.). Diatoms of Europe Diatoms of the European Inland Waters and Comparable Habitats. Koeltz Botanical Books: 552 pp.

[39] Lobo, E.A., Callegaro, V.L.M., Hermany, G., Bes, D., Wetzel, C.A., Oliveira, M.A. (2004): Use of epilithic diatoms as bioindicators from lotic systems in southern Brazil, with special emphasis on eutrophication. Acta Limnologica Brasiliensia 16 (1): 25-40. 
[40] Mykrä, H., Heino, J., Oksanen, J., Muotka, T. (2011): The stability-diversity relationship in stream macroinvertebrates: influences of sampling effects and habitat complexity. Freshwater Biology 56 (6): 1122-1132. doi: 10.1111/j.13652427.2010.02555.x

[41] ReICHARDT, E. (1997): Taxonomische Revision des Artenkomplexes um Gomphonema pumilum (Bacillariophyceae). Nova Hedwigia 65: 99-129. doi: 10.1127/nova.hedwigia/65/1997/99

[42] ReICHARDT, E. (1999): Zur Revision der Gattung Gomphonema: Die Arten um G. affine/insigne, G. angustatum/micropus, G. acuminatum sowie Gomphonemoide Diatomeen aus dem Oberoligozän in Böhmen. In: Lange-Bertalot, H. (ed.). Iconographia Diatomologica 8. Gantner Verlag: 203 pp.

[43] Reichardt, E., LANGe-Bertalot, H. (1991): Taxonomische Revision des Artenkomplexes um Gomphonema angustum-G. dichotomum-G. intricatum-G. vibrio und ähnliche Taxa (Bacillariophyceae). Nova Hedwigia 53: 519-544.

[44] Simić, S., Petrović, A., ĐorĐević, N., VAsiljević, B., Radojković, N., Mitrović, A., JANKOVIĆ, M. (2018): Indicative ecological status assessment of the Despotovica River. Kragujevac Journal of Science 40: 227-242. doi: 0.5937/KgJSci1840227S

[45] Soininen, J., Eloranta, P. (2004): Seasonal persistence and stability of diatom communities in rivers: are there habitat specific differences? European Journal of Phycology 39 (2): 153-160. doi: 10.1080/0967026042000201858

[46] Ter BraAk, C.J., SMilauer, P. (2012): Canoco reference manual and user's guide: software for ordination, version 5.0. Microcomputer power, Ithaca, USA: $496 \mathrm{pp}$.

[47] Trobajo, R., Rovira, L., Ector, L., Wetzel, C.E., Kelly, M., Mann, D.G. (2012): Morphology and identity of some ecologically important small Nitzschia species. Diatom Research 28 (1): 37-59. doi: 10.1080/0269249X.2012.734531

[48] Van Dam, H., Mertens, A., Sinkeldam, J. (1994): A coded checklist and ecological indicator values of freshwater diatoms from The Netherlands. Netherlands Journal of Aquatic Ecology 28 (1): 117-133. doi: 10.1007/BF02334251

[49] VAN DE ViJVer, B., Beyens, L., LANGe-Bertalot, H. (2004): The genus Stauroneis in the Arctic and (sub-) Antarctic-regions. In: Lange-Bertalot, H., Kociolek P. (eds.). Bibliotheca Diatomologica. Cramer, Berlin, Stuttgart: 317 pp.

[50] ViRTANEN, L. (2015): Temporal and spatial turnover of freshwater diatoms. PhD Thesis, University of Helsinki, Helsinki, Finland.

[51] Wagner, B., Wilke, T., Francke, A., Albrecht, C., Baumgarten, H., Bertini, A., Combourieu-Nebout, N., Cvetkoska, A., Addabbo, M., Donders, T.H., Föller, K., Giaccio, B., Grazhdani, A., Hauffe, T., Holtvoeth, J., Joannin, S., Jovanovska, E., Just, J., Kouli, K., Koutsodendris, A., Krastel, S., Lacey, J.H., Leicher, N., Leng, M.J., Levkov, Z., Lindhorst, K., Masi, A., Mercuri, A.M., Nomade, S., Nowaczyk, N., Panagiotopoulos, K., Peyron, O., Reed, J.M., Regattieri, E., Sadori, L., Sagnotti, L., Stelbrink, B., Sulpizio, R., Tofilovska, S., Torri, P., Vogel, H., Wagner, T., Wagner-Cremer, F., WolfF, G.A., Wonik, T., ZanchetTA, G., ZHANG X.S. (2017): The environmental and evolutionary history of Lake Ohrid (FYROM/Albania): interim results from the SCOPSCO deep drilling project. Biogeosciences 14: 2033-2054. doi: 10.5194/bg-14-2033-2017 